\title{
Hubungan Self Efficacy Terhadap Prokrastinasi Guru Pendidik Di SMP N 1 Kretek
}

\author{
Fahmawanti S. Dwi Rio S. Leo Trihartantyo \\ Pascasarjana Magister Psikologi, Universitas Ahmad Dahlan "UAD" Yogyakarta \\ Email: fahmasekar2@gmail.com, dwi_rio@ @rocketmail.com, leotrihartantyo@gmail.com
}

\begin{abstract}
This study aims to find out the relationship between self-efficacy and procrastination of teachers in Kretek 1 Junior High School with a sample of 34 teachers consisting of female and male teachers. The data collection of the research sample was carried out by random sampling model where every individual in the population gets the same opportunity to become participants for research subjects. This research using the scale of procrastination (Alpha 0.781) and the scale of self-efficacy (Alpha 0.820). Research data analysis was performed by the product moment with SPSS 19 for windows program. The results showed that the correlation coefficient between the two variables was $-0,524$ with $p=0.001(<0.05)$. The results concluded that there was a significant relationship between self-efficacy and procrastination, therefore the hypothesis in this study was accepted.
\end{abstract}

Keyword: Self efficacy, Procrastination, Educator

\begin{abstract}
Abstrak
Penelitian ini dilakukan untuk mengetahui hubungan antara self-efficacy dengan prokrastinasi guru pendidik di SMP N 1 Kretek dengan sampel penelitian berjumlah 34 guru yang terdiri dari guru perempuan dan laki-laki. Pengambilan data menggunakan model random sampling dimana setiap individu dalam populasi mendapat kesempatan yang sama untuk menjadi partisipan atau subjek penelitian. Metode penelitian menggunakan skala prokrastinasi (Alpha 0,781) dan self-efficacy (Alpha 0,820). Teknik analisis yang digunakan adalah product moment dengan program SPSS 19 for windows. Hasil penelitian menunjukkan bahwa koefisien korelasi antara dua variabel yaitu -0.524 dengn $\mathrm{p}=0.001(<0.05)$. Hasil tersebut disimpulkan bahwa terdapat hubungan yang signifikan antara self-efficacy dengan prokrastinasi, oleh karenanya hipotesis dalam penelitian ini diterima.
\end{abstract}

Kata Kunci: Efikasi Diri, Prokrastinasi, Guru Pendidik

\section{Pendahuluan}

Tugas merupakan salah satu tuntutan dalam sebuah pekerjaan yang harus diselesaikan dalam batasan waktu tertentu. Saat mengerjakan tugas setiap individu memiliki kemampuan yang berbeda-beda, ada individu yang cenderung dengan cepat menyelesaikan tugasnya ada juga yang cenderung menunda untuk menyelesaikan tugasnya. Oleh karena itu, perilaku yang tidak efisien dalam menggunakan waktu dan adanya kecenderungan untuk tidak segera memulai suatu pekerjaan ketika menghadapi suatu tugas disebut dengan prokrastinasi (Ghufron \& Rini, 2010). Menurut Kurniawati dan Astuti (2008), jika seseorang pegawai melakukan prokrastinasi atau penundaan dalam pekerjaannya, maka akan timbul masalah dalam pekerjaan yang mereka tunda. Pekerjaan pegawai tersebut akan terus menumpuk sehingga semakin terbebani dengan pekerjaan tersebut. Mereka akan dikejar batas waktu penyelesaian pekerjaan dengan target yang harus dipenuhi, padahal pekerjaan tersebut tertunda. Melihat pada kondisi atau kenyataan sekarang di kantor-kantor instansi pemerintah, misalnya kantor kelurahan dan dinas masih terlihat banyak pegawai yang tidak optimal dalam mengerjakan tugasnya pada saat jam kerja kantor. Hal ini tampak dari perilaku yang ditampilkan seperti membaca koran atau majalah, bercakap-cakap dengan rekannya, pergi ke kedai kopi di waktu jam kerja bukan untuk alasan dinas. Kondisi tersebut menggambarkan bahwa di kantor pemerintah banyak para pegawai yang relatif sering melakukan prokrastinasi kerja sehingga sangat merugikan masyarakat yang sebenarnya sangat membutuhkan pelayanan jasa dengan cepat (kompasiana, 26/06/15).

Berdasarkan hasil wawancara pada tiga orang guru disalah satu sekolah negeri mendapatkan data bahwa terdapat beberapa guru yang melakukan penundaan pada pekerjaan yang diberikan. Guru sering menunda pekerjaan mereka hingga batas waktu yang diberikan. Salah satu contoh yaitu tugas 
membuat laporan administrasi pekerjaan guru. Tugas tersebut seharusnya di laporan setiap seminggu sekali, tetapi banyak guru yang tidak mengumpulkan laporan tersebut secara tepat waktu. Menurut Burka dkk (dalam Ghufron \& Rini, 2010), menyatakan bahwa prokrastinator memandang tugas sebagai sesuatu yang berat dan tidak menyenangkan. Oleh karena itu, seseorang merasa tidak mampu menyelesaikan tugasnya secara memadai sehingga menunda-nunda menyelesaikan tugas tersebut. Menghadapi penyebab prokrastinasi tersebut diperlukan keyakinan akan kemampuannya untuk menghadapi permasalahan dan melakukan tindakan yang dibutuhkan dalam menyelesaikan tugas untuk menghadapi hasil yang diharapkan. Keyakinan seseorang akan kemampuan yang dimiliki berdasarkan Bandura di sebut dengan istilah self-efficacy. Seperti yang dikatakan Steel (2007) bahwa self-efficacy memiliki peranan cukup penting dalam kemunculan prokrastinasi. Keinginan melakukan sesuatu hal akan menjadi tinggi ketika harapan keberhasilan juga tinggi. Sehingga tingkat prokrastinasi akan menjadi rendah (Steel, 2007). Berdasarkan uraian diatas, maka peneliti tertarik menguji secara lebih lanjut mengenai hubungan self-efficacy terhadap prokrastinasi guru pendidik si SMP N 1 Kretek.

\section{Prokrastinasi}

Prokrastinasi (kecenderungan untuk menunda ketika menghadapi tugas atau tidak segera menyelesaikan tugas yang dimiliki) pada dasarnya berasal dari dua bahasa latin yaitu "pro" yang berarti motivasi mendorong untuk bergerak maju dan "crastinus" berarti untuk hari esok (Ferrari,Johnson \& McCown, 1995). Knauss (2010) menyebutkan bahwa prokrastinasi sebagai suatu masalah kebiasaan (bersifat otomatis) dalam menunda suatu hal atau kegiatan yang penting dan berjangka waktu sampai waktu yang telah ditentukan habis. Prokrastinasi terbagi menjadi dua jenis yaitu prokrastinasi akademik dan prokrastinasi non-akademik. Prokrastinasi akademik adalah penundaan tugas yang dilakukan oleh seseorang dalam hal akademik (Ferrari, Johnson \&McCown, 1995). Faktor yang mempengaruhi prokrastinasi akademik yaitu faktor internal dan faktor eksternal. Faktor internal merupakan pengaruh prokrastinasi yang didapat dari dalam diri individu itu sendiri, sedangkan faktor eksternal yaitu pengaruh prokrastinasi didapat dari luar individu misalnya pengasuhan orangtua dan lingkungan. Faktor internal yang mempengaruhi prokrastinasi akademik dalam diri individu antara lain kondisi fisik seperti kelelahan, dan kondisi psikologis seperti keraguan dan motivasi (Ferrari, Johnson \& McCown, 1995).

Faktor yang mempengaruhi prokrastinasi yaitu faktor internal dan faktor eksternal. Faktor internal merupakan pengaruh prokrastinasi yang didapat dari dalam diri individu itu sendiri, sedangkan faktor eksternal yaitu pengaruh prokrastinasi didapat dari luar individu misalnya pengasuhan orangtua dan lingkungan. Faktor internal yang mempengaruhi prokrastinasi akademik dalam diri individu antara lain kondisi fisik seperti kelelahan, dan kondisi psikologis seperti keraguan dan motivasi (Ferrari, Johnson \& McCown, 1995). Menurut Van Eerde, faktor-faktor yang berkorelasi dengan prokrastinasi adalah a) Demographic (Usia, jenis klamin, atau pendidikan juga dapat berdampak pada penundaan, karena memiliki nilai-nilai dan juga pengalaman yang berbeda), b) Personality Variable (Perilaku individu berkaitan dengan sejumlah penundaan, individu yang memiliki kesadaran yang rendah akan cenderung menunda-nunda pekerjaan. Individu yang tinggi neurotis nya juga cendrung menundanunda tugas), c) Self-image (Menunda tugas sangat berkaitan dengan harga diri yang rendah), d) Motives (Perfeksionis dan takut gagal telah dijadikan alasan sebagai menghindari tugas-tugas. Penundaan dilakukan karena tidak ingin mendapatkan feedback yang negatif), e) Affect (Afeksi mempengaruhi prokrastinasi ketika ada hasil negatif psikologi seperti cemas atau depresi seseorang akan cendrung menunda tugas karena perasaan tersebut muncul), f) Performance (Penundaan dapat dipengaruhi oleh ketersediaan waktu pengerjaan tugas yang diberikan).

Ferrari \& McCown (1995) menyatakan aspek-aspek prokrastinasi meliputi a) Perceived time (Seseorang yang cenderung prokrastinasi adalah orang-orang yang gagal menepati deadline. Mereka berorientasi pada masa sekarang dan tidak mempertimbangkan masa mendatang. Prokrastinator tahu bahwa tugas yang dihadapinya harus segera diselesaikan, tetapi ia menunda-nunda untuk mengerjakannya atau menunda menyelesaikannya jika ia sudah memulai pekerjaannya tersebut. Hal ini mengakibatkan individu tersebut gagal memprediksikan waktu yang dibutuhkan untuk mengerjakan tugas), b) Intention-action (celah antara keinginan dan tindakan. Perbedaan antara keinginan dengan tindakan senyatanya ini terwujud pada kegagalan siswa dalam mengerjakan tugas akademik walaupun siswa tersebut punya keinginan untuk mengerjakannya. Ini terkait pula dengan 
kesenjangan waktu antara rencana dan kinerja actual. Prokrastinator mempunyai kesulitan untuk melakukan sesuatu sesuai dengan batas waktu. Seorang siswa mungkin telah merencanakan untuk mulai mengerjakan tugasnya pada waktu yang telah ia tentukan sendiri, akan tetapi saat waktunya sudah tiba dia tidak juga melakukan sesuatu sesuai dengan apa yang telah ia rencanakan sehingga menyebabkan keterlambatan atau bahkan kegagalan dalam menyelesaikan tugas secara memadai), c) Emotional distress (adanya perasaan cemas saat melakukan prokrastinasi. Perilaku menunda-nunda akan membawa perasaan tidak nyaman pada pelakunya. Konsekuensi negative yang ditimbulkan memicu kecemasan dalam diri pelaku prokrastinasi. Pada mulanya siswa tenang karena merasa waktu yang tersedia masih banyak. Tanpa terasa waktu sudah hampir habis, ini menjadikan mereka merasa cemas karena belum menyelesaikan tugas), d) Perceived ability (keyakinan terhadap kemampuan diri). Walaupun prokrastinasi tidak berhubungan dengan kemampuan kognitif seseorang, namun keragu-raguan terhadap kemampuan dirinya dapat menyebabkan seseorang melakukan prokrastinasi. Hal ini ditambah dengan rasa takut akan gagal menyebabkan seseorang menyalahkan dirinya sebagai yang tidak mampu untuk menghindari munculnya dua perasaan tersebut.

\section{Self- Efficacy}

Seseorang bertingkah laku dalam situasi tertentu pada umumnya dipengaruhi oleh faktor lingkungan dan kognitif, khususnya faktor kognitif yang berhubungan dengan keyakinan bahwa dirinya mampu atau tidak mampu melakukan tindakan yang memuaskan. Keyakinan atau yang disebut self-efficacy yang diungkapkan oleh Bandura (1997) yakni merupakan persepsi diri mengenai seberapa bagus diri dapat berfungsi dalam situasi tertentu. Self-efficacy juga merupakan penilaian diri, apakah dapat melakukan tindakan yang baik atau buruk, tepat atau salah, bisa atau tidak bisa mengerjakan sesuai dengan yang dipersyaratkan. Maka dapat dilihat bahwa self-efficacy menggambarkan penilaian kemampuan diri (Alwilsol, 2004). Bandura (1997) mengemukakan beberapa dimensi self-efficacy yaitu a) Magnitude atau level (persepsi individu mengenai kemampuannya yang diukur melalui tingkat kesulitan dengan berbagai macam kesulitan tugas. Individu yang memiliki tingkat kesulitan tugas yang tinggi memiliki kekyakinan bahwa dirinya mampu mengerjakan tugas-tugas yang sukar dan juga memiliki self-efficacy yang tinggi, sedangkan individu dengan tingkat kesulitan tugas yang rendah memiliki keyakinan bahwa dirinya hanya mampu mengerjakan tugas-tugas yang mudah serta memiliki self-efficacy yang rendah), b) Generality (individu menilai keyakinan mereka berada pada tingkat kesulitan tugas tertentu dalam arti luas individu mempunyai keyakinan dalam melaksanakan tugas-tugas. Generalisasi memiliki perbedaan dimensi yang bervariasi yaitu intensitas kesamaan aktivitas, kemampuan yang ditunjukkan dengan tingkah laku, kognitif, afektif. Menggambarkan secara nyata mengenai situasidan karakteristik perilaku individu yang ditunjukkan. Penilaian ini berkaitan dengan perilaku dan konteks situasi yang mengungkapkan keyakinan individu terhadap keberhasilan mereka), c) Strength (berkaitan dengan kuat-lemahnya keyakinan seorang individu. Individu yang memiliki keyakinan yang kuat akan bertahan dengan usaha mereka meskipun ada banyak kesulitan dan hambatan).

\section{Metode Penelitian}

Penelitian ini merupakan penelitian korelasional, yaitu penelitian yang bertujuan menyelidiki sejauhmana variasi pada satu variabel berkaitan dengan variasi pada satu atau lebih variabel lain berdasarkan koefisien korelasi (Azwar, 2009). Penelitian ini dilakukan dengan metode pengambilan data menggunakan kuosioner yang melibatkan partisipan sejumlah 34 guru. Prosedur dalam penelitian ini adalah peneliti datang ke sekolah untuk meminta izin dan persetujuan dari pihak sekolah kemudian dilanjutkan dengan pengambilan data yaitu penyebaran skala.

Subjek dalam penelitian ini adalah 34 guru SMP N 1 Kretek yang terdiri dari guru perempuan dan guru laki-laki. Metode pengambilan data menggunakan model random sampling dimana setiap individu dalam populasi mendapat kesempatan yang sama untuk menjadi partisipan atau subjek penelitian. Metode pengambilan data dalam penelitian ini menggunakan kuesioner yang didalamnya terdapat tiga skala untuk mengukur masing-masing variabel. Skala yang digunakan adalah skala 
prokrastinasi dan skala self-efficacy. Instrumen penelitian ini menggunakan skala model Likert, dimana terdapat 3-5 alternatif jawaban.

Skala prokrastinasi disusun berdasarkan teori Ferrari \& McCown (1995) yang terdiri dari empat aspek yaitu perceived time, intention-action, emotional distress, perceived ability. Pilihan dalam jawaban ini adalah sangat sesuai (SS), sesuai (S), tidak sesuai (TS), dan sangat tidak sesuai (STS). Pemberian skor pada masing-masing aitem dengan cara memberikan nilai 1 sampai 4. Jawaban sangat sesuai (SS) diberi nilai 4, sesuai (S) diberi nilai 3, tidak sesuai (TS) diberi nilai 2, dan sangat tidak sesuai (STS) diberi nilai 1 dengan skor total yang diperoleh malai dari 10-40. Skala self-efficacy (GSE) Schwarzer \& Jarusalem (1995) berjumlah 10 aitem yang merupakan skala unidimensional artinya 10 aitem telah mencakup didalamnya aspek magnitude, generality, dan strength. Skala disusun berdasarkan modifikasi model skala Likert yang dibuat dalam empat alternative yaitu sangat sesuai (SS), sesuai (S), tidak sesuai (TS), dan sangat tidak sesuai (STS). Pemberian skor pada masing-masing aitem dengan cara memberikan nilai 1 sampai 4. Untuk jawaban sangat sesuai (SS) diberi nilai 4, sesuai (S) diberi nilai 3, tidak sesuai (TS) diberi nilai 2, dan sangat tidak sesuai (STS) diberi nilai 1 dengan skor total yang diperoleh mulai dari 10-40. Analisis data dalam penelitian ini menggunakan analisis regresi ganda (multiple regretion) yaitu teknik statistik yang digunakan untuk menganalisis hubungan antara satu variabel dependen dan beberapa variabel bebas. (Sugiyono, 2003). Terdapat dua variabel dalam penelitian ini yaitu variabel prokrastinasi dan self-efficacy, Aspek prokrastinasi yang digunakan adalah Perceived time, Intention-action, Emotional distress, Perceived ability. Aspek self-efficacy yang digunakan adalah Magnitud, Generality, Strength.

\section{Hasil dan Pembahasan}

Hasil analisis reliabilitas pada kedua skala menggunakan formula Alpha Cronbach diperoleh bahwa kedua skala dapat digunakan sebagai alat pengumpul data. Skala prokrastinasi menghasilkan Cronbach's Alpha 0,781 dengan total aitem 10 aitem pada variabel self efficacy dan variabel prokrastinasi menghasilkan Cronbach's Alpha 0.820 dengan total aitem tersisa 10 aitem.

Tabel. Analisis Data

Correlations

\begin{tabular}{|c|c|c|c|}
\hline & & & Prokrastinas \\
\hline & & Self Efficacy & $\mathrm{i}$ \\
\hline \multirow{4}{*}{$\begin{array}{l}\text { Self } \\
\text { Efficacy }\end{array}$} & Pearson & \multirow{2}{*}{1} & \multirow{2}{*}{$-.524^{* * *}$} \\
\hline & Correlation & & \\
\hline & Sig. (2-tailed) & \multicolumn{2}{|r|}{.001} \\
\hline & $\mathrm{N}$ & 34 & 34 \\
\hline \multirow{4}{*}{$\begin{array}{l}\text { Prokrastinas } \\
\text { i }\end{array}$} & Pearson & \multirow{2}{*}{$-.524^{* *}$} & \multirow{2}{*}{1} \\
\hline & Correlation & & \\
\hline & Sig. (2-tailed) & .001 & \\
\hline & $\mathrm{N}$ & 34 & 34 \\
\hline
\end{tabular}

Korelasi Pearson atau sering disebut korelasi product moment (KPM) merupakan alat uji statistik yang digunakan untuk menguji hipotesis asosiatif (uji hubungan) dua variabel bila datanya berskala interval atau rasio. KPM dikembangkan oleh Karl Pearson (Hasan, 1999). Hipotesis dinyatakan diterima jika $\mathrm{p}<0.05$ (signifikan) atau $\mathrm{p}<0.01$ (sangat signifikan) dan tidak diterima jika $\mathrm{p}>0.05$. Tabel diatas dapat diketahui pearson correlation menunjukkan koefisien korelasi antara dua variabel yaitu 0.524 dan p nya adalah 0.001. Berdasarkan hasil tersebut maka dapat disimpulkan bahwa hipotesis tersebut diterima karena adanya hubungan yang signifikan antara Self efficacy dengan prokrastinasi.

Self-efficacy yang dimiliki oleh guru akan berpengaruh terhadap prokrastinasi yang dilakukan. Semakin tinggi self-efficacy yang dimiliki oleh guru maka akan semakin rendah prokrastinasi yang dilakukan, begitu juga sebaliknya semakin rendah self-efficacy yang dimiliki oleh guru makan akan semakin tinggi prokrastinasi yang dilakukan. Hal ini sejalan degan penelitian Irawan (2015) bahwa semakin rendah ringkat self-efficacy pegawai maka semakin tinggi tingkat prokrastinasinya. Semakin 
pegawai merasa tidak yakin terhadap kemampuan dirinya maka pegawai akan semakin cenderung untuk melakukan penundaan pekerjaan mereka. Steel (dalam Lasmono, 2008) menyatakan bahwa prokrastinasi dipengaruhi oleh faktor perbedaan individu, salah satunya adalah self-efficacy. Bandura (1997) menyatakan bahwa salah satu hal yang memengaruhi timbulnya prokrastinasi karyawan adalah self-efficacy. Self-efficacy adalah keyakinan yang dimiliki individu bahwa dirinya akan mampu menyelesaikan tugas-tugas tertentu hingga tuntas. Self-efficacy banyak berperan dalam pencapaian tujuan dan kinerja individu dalam dunia kerja. Salah satu proses yang mempengaruhi self-efficacy adalah proses kognitif. Mayoritas tindakan manusia bermula dari sesuatu yang difikirkan terlebih dahulu. Individu yang memiliki self-efficacy tinggi akan lebih senang membayangkan tentang kesuksesan. Sebaliknya individu yang memiliki self-efficacy rendah akan lebih banyak membayangkan kegagalan dan hal-hal yang dapat menghambat tercapainya kesuksesan dan menganggap hal-hal tersebut merupakan hal yang sulit diselesaikan. Seorang guru yang memiliki selfefficacy tinggi akan mampu mengerjakan berbagai tugas yang sulit sekalipun dengan tidak menundanunda tugas tersebut (Bandura, 1997).

Self-efficacy dapat menjadikan guru terhindar dari prokrastinasi kerja yang dapat merugikan sekolah pada umumnya dan juga diri sendiri. Prokrastinasi sendiri juga dapa berdampak pada peningkatan stress terhadap pekerjaan yang mana penundaan dianggap sebagai perilaku yang menyulitkan diri sendiri karena mengarah pada waktu yang terbuang sia-sia (Beheshtifar, 2011). Prokrastinator pasif dilumpuhkan oleh keragu-raguan mereka dan akibatnya gagal menyelesaikan tugas tepat waktu, jadi ini tentu saja merupakan perilaku yang tidak menguntungkan (Gafni, 2010). Sawitri (2009) yang menunjukkan bahwa individu dengan self-efficacy akan berusaha melakukan penilaian diri, pencarian informasi, melakukan pemilihan, membuat perencanaan, dan memecahkan masalah. Self-efficacy akan membantu individu dalam membuat suatu keputusan beberapa individu bertahan dalam menghadapi rintangan dan pengalaman yang menyakitkan.

Self-efficacy pada guru akan membantu dalam menyelesaikan tugas dengan baik tanpa harus menunjukkan prokrastinasi kerja yang dapat merugikan diri sendiri dan instansi sekolah pada umumnya. Hasil penelitian yang dilakukan Muhid (2008) menunjukkan bahwa terdapat hubungan yang signifikan antara self-efficacy dengan kecenderungan prokrastinasi. Individu yang memiliki selfefficacy tinggi akan selalu mencoba melakukan berbagai tindakan dan siap menghadapi kesulitankesulitan dan menentukan seberapa besar usaha yang dikeluar dalam tugas-tugas. Sejalan dengan hasil penelitian tersebut, hasil penelitian yang dilakukan Rahardjo dan Lee (2011) menunjukkan bahwa self-efficacy jelas memainkan peranan penting terhadap kecenderungan prokrastinasi yang dilakukan karyawan. Self-efficacy akan dapat menjadikan individu terhindar dari prokrastinasi dikarenakan adanya keyakinan untuk dapat melakukan suatu tugas tanpa harus terpuruk dengan kesulitan yang muncul dalam suatu tugas. Darmawan (2017) menyebutkan bahwa semakin rendah self-efficacy pegawai maka prokrastinasi akan semakin tinggi. Semakin pegawai merasa tidak yakin akan kemampuan dirinya maka pegawai akan cenderung semakin melakukan penundaan dalam mengerjakan tugasnya. Hal serupa juga disampaikan oleh Sandra dan Muhammad (2013) bahwa semakin tinggi efikasi diri pada guru maka semakin berkurang perilaku prokrastinasi, sebaliknya semakin rendah efikasi diri pada guru maka semakin tinggi untuk melakukan kecenderungan prokrastinasi.

\section{Kesimpulan}

Berdasarkan hasil analisis dan pembahasan dapat disimpulkan bahwa ada hubungan yang signifikan antara self-efficacy dan prokrastinasi. Semakin tinggi self-efficacy maka akan semakin rendah prokrastinasi yang dilakukan, begitu juga sebaliknya bahwa semakin rendah self-efficacy maka akan semakin tinggi prokrastinasi. Peneliti selanjutnya disarankan agar melakukan penelitian pada sampel yang lebih besar dan beragam, serta menambah variabel lain yang dapat mempengaruhi prokrastinasi karyawan. Hal tersebut bertujuan untuk membantu organisasi dalam mengelola SDM sehingga dapat menghasilkan kinerja optimal yang dapat meningkatkan kualitas organisasi.

\section{Daftar Rujukan}

[1] Azwar, S. (2009). Sikap Manusia, Teori dan Pengukurannya. Jakarta : Pustaka Pelajar. 
[2] Baheshtifar, M., Hadis, H., dan Mahmoud, N. M. (2011). Effect Procrastination on Work-Related Stress. European Journal of Economics, Finance And Administrative Sciences. ISSN 1450-2275

[3] Bandura, A. (1997). Self Efficacy The Exercise Of Control. New York: W.H. Freeman and Company.

[4] Darmawan, F. W., Lisa W., dan Anna R. (2017). Hubungan antara Self Efficacy dengan Prokrastinasi Pada Karyawan Departemen Perakitan PT. Pindan (Persero) Bandung. Prosiding Psikologi Gelombang 2. Vol 3. No.2. Hal 922-928. Bandung: : Penelitian Sivitas Akademika Unisba (Sosial \& Humaniora).

[5] Ferrari, J.R. Johnson, J.L. \& Mc Cown, W.G. (1995). Procrastination and task Avoidance, Theory, Research and Treathment. New York: Plenum Press

[6] Gafni, R. \& Ger, N., 2010. "Time Management: Procrastination Tendency in Individual and Collaborative Tasks". Interdisciplinary Journal of Information, Knowledge, and Management. 5, PP.116-123.

[7] Ghufron, M. Nur dan Rini Risnawita S. (2010). Teori-Teori Psikologi, Cetakan I. Yogyakarta: Ar Ruzz Media Group

[8] Irawan, I., Ali M., (2015). Hubungan Self Efficacy dengan Procrastination pada Pegawai Departemen Pemesinan PT. PINDAD (Persero). Prosiding Psikologi Gelombang 2, tahun akademik 2014-2015. Bandung: Penelitian Sivitas Akademika Unisba (Sosial \& Humaniora).

[9] Knauss, William. (2010). End Procrastination Now!. United States: McGrawHill.

[10]Kompasiana. (2015). Penyakit prokrastinasi menunda pekerjaan.http://www.kompasiana.com/hamamburhanudin/penyakit-prokrastinasi-menundapekerjaan_5508848f8133119f14b1e1ec. Diakses 1 Oktober 2019

[11] Kurniawati, Fitria Nur Indah dan Yulianti Dwi Astuti. (2008). Hubungan Antara Prokrastinasi Dan Stres Kerja Pada Karyawan PT. Armada Finance Magelang. http://psychology.uii.ac.id/images/stories/jadwalkuliah/naskah-publikasi-04320163.pdf. Diakses pada tanggal 1 Oktober 2019.

[12] Lasmono, H. K., Gunawinata, V. A. R., dan Nanik. (2008). Perfeksionisme, Prokrastinasi Akademik dan Penyelesaian Skripsi Mahasiswa. Anima. Vol. 23. No. 3. Hal. 256-276. Surabaya: Fakultas Psikologi Universitas Surabaya.

[13] Muhid, A. (2008). Hubungan antara Self-Control dan Self Effiacy dengan Kecenderungan Perilaku Prokrastinasi Akademik Mahasiswa. Jurnal Psikologi. Hal. 1-15. Surabaya: Program Studi Psikologi IAIN Sunan Ampel Surabaya

[14] Rahardjo, W., dan Lee, FX, Y. (2011). Prokrastinasi Keterbangkitan dan Menghindar: Kaitannya dengan Efikasi Diri pada Karyawan. Seminar Peran Psikologi dalam Boundaryless Organization: Strategi Mempersiapkan SDM Berkualitas. Hal. 138-13. Fakultas Psikologi Universitas Gunadarma.

[15] Raharjo, W. dan Yoseptan L. (2011). Prokrastinasi Keterbangkitan dan Menghindar: Kaitannya dengan Efikasi Diri Pada Karyawan. In: Semnas Peran Psikologi Dalam Boundaryless, Strategi Mempersiapkan SDM Bertalenta. 23-24 September 2011. Semarang

[16] Sandra, K. I., dan Muhammad, A. D. (2013). Manajemen Waktu, Efikasi Diri, dan Prokrastinasi. Jurnal Psikologi Indonesia (Persona). Vol.2, No. 3, Hal. 217-222. September 2013. Surabaya: Universitas 17 Agustus 1945.

[17] Sawitri, D. R. (2009). Pengaruh Status Identitas dan Efikasi Diri Keputusan Karir terhadap Keraguan Mengambil Keputusan Karir pada Mahasiswa Tahun Pertama di Universitas Diponegoro. Jurnal Psikologi Undip. Vol. 5, No. 2, Hal. 1-14. Desember 2009.Semarang: Fakultas Psikologi Universitas Diponegoro.

[18] Steel, Piers. (2007). The Nature Of Procrastination: A Meta-Analytic and Theoretical Review of Quintessential Self-Regulatory Failure. Psychological Bulletin, 133 (1), 65-94

[19] Sugiyono. (2003). Metode Penelitian Bisnis Edisi 1. Bandung: Alfabeta.

[20] Suryabrata, S., (2005). Pengembangan Alat Ukur Psikologis. Yogyakarta: Andi. 